\title{
Effects of different nitrogen and potassium sources on lettuce (Lactuca sativa L.) yield in a sandy soil
}

\author{
Mohamed Said Awaad *, Ragab Ali Badr, Mamoduh Ali Badr, \\ Ahmed Hamada Abd-elrahman
}

Soil, Water and Environment Research Institute (SWERI), Agricultural Research Center, Giza, Egypt

\section{Article Info}

Received : 05.01.2016

Accepted : 18.04 .2016

\begin{abstract}
Lettuce plants were grown under sandy soil conditions in the private farm of Ahmed Orabi organization, Cairo Governorate Egypt, between 15th November 2009 and 15 January 2010. The experiment was conducted to assess the effects of different nitrogen sources, slow release $\mathrm{N}$ (urea-formaldehyde) and fast release $\mathrm{N}$ (urea) containing fertilizers at the rates of 0, 60, 90 and $120 \mathrm{~kg} \mathrm{~N} \mathrm{ha}^{-1}$ applied alone or combined with potassium sulphate, on lettuce plant yield. Results indicated that application of different sources of $\mathrm{N}$ alone or combined with potassium sulphate gave the highest fresh dry weight per plant and total lettuce yield per hectare compared with the control. The highest dry weight of lettuce was achieved with the combination of urea and potassium sulphate. Although fertilization made with the combination of urea and potassium sulphate resulted in the highest $\mathrm{P}, \mathrm{K}, \mathrm{Zn}$ and $\mathrm{Mn}$ contents in lettuce plant, fertilization with urea alone gave the highest $\mathrm{N}$ and $\mathrm{Fe}$ contents. The lowest content of nitrate in lettuce plants was recorded with the fertilization of urea only or with the combination of urea and potassium sulphate. Application of the combination of urea and potassium sulphate induced the highest protein content in plants. The results indicated that application of urea-formaldehyde as a slow release nitrogen fertilizer solely or combined with potassium sulphate significantly improved yield and yield quality of lettuce plants grown in sandy soil.
\end{abstract}

Keywords: Urea-formaldehyde, urea, potassium sulphate, Lactuca sativa.

(C) 2016 Federation of Eurasian Soil Science Societies. All rights reserved

\section{Introduction}

Lettuce (Lactuca sativa L.) is the most popular crop among the salad vegetables, which requires nitrogen (N) for growth and development. Nitrogen fertilizers such as; ammonium sulphate, ammonium nitrate or calcium nitrate positively affects fresh and dry plant weights, plant diameter and the number of total marketable leaves, whereas the yield and other yield components remained unaffected by $\mathrm{N}$ sources (Bozkurt et al., 2009, Gülser et al., 2010). Plants absorb $\mathrm{N}$ from the soil in the form of ammonium $\left(\mathrm{NH}_{4}{ }^{+}\right.$) and nitrate $\left(\mathrm{NO}_{3}{ }^{-}\right)$, which is converted into $\mathrm{NH}_{4}{ }^{+}$to forms of proteins and other $\mathrm{N}$ containing substances in plant (Cash et al., 2002). Some vegetable crops, especially those with short lifespan such as lettuce, have the ability to accumulate proportionally nitrate. Nitrate accumulation in plant can be hazardous to human health because nitrate can be reduced to nitrite in the body and cause methemoglobinemia. Furthermore, there is a possibility of formations of $\mathrm{N}$-niroso compounds from nitrite and secondary $\mathrm{N}$ compounds in the human stomach (Breimer, 1982). According to WHO (1995), the acceptable daily intake of nitrate is between 0 and $3.65 \mathrm{mg} \mathrm{kg}^{-1}$ of body weight. Leafy vegetables such as spinach, lettuce and celery contain nitrate at significant levels (Maynard et al., 1976). Many studies were conducted to decrease nitrite and nitrate accumulation in vegetables. Byrne et al. (2001) found that increasing rates of $\mathrm{N}$ in soils caused an increase in nitrate accumulation in lettuce, particularly in outer leaves. Moreover, there are evidences that the slow release $\mathrm{N}$

\footnotetext{
${ }^{*}$ Corresponding author.

Soil, Water and Environment Research Institute (SWERI), Agricultural Research Center, Giza, 12112 Egypt

Tel.: +201006988461

E-mail address: moayamai@yahoo.com 
fertilizers increased the efficiency use of $\mathrm{N}$ and minimized the loss of $\mathrm{N}$ in form of ammonia gas $\left(\mathrm{NH}_{3}\right)$ by volatilization and leaching of $\mathrm{NO}_{3}$ - from soils, which pollute the underground water. Hegde (1997) reported that application of slow release $\mathrm{N}$ fertilizers was very effective in increasing nutrient use efficiency, crop production and reducing nutrient lose.

Potassium $(\mathrm{K})$ is an essential nutrient element for plant growth and taken up from the soil solution by the plant roots in the form of potassium ion $\left(\mathrm{K}^{+}\right)$. Potassium is very mobile within the plant and its deficiency symptoms in plants appear first in the old leaves (Tisdale et al., 1993). Potassium is directly involved in enzyme activation, maintenance of water status, energy relations, and translocation of assimilates and protein synthesis. $\mathrm{K}$ regulates cellular turgid pressure to avoid wilting, which in turn controls the stomata opening and hence greatly enhances drought tolerance (McCarty, 2005). Potassium occurs as single-valued K cation; however, $\mathrm{K}$ containing fertilizers differ in their accompanying anions i.e. $\mathrm{Cl}-\mathrm{SO}_{4}{ }^{-2}$ and $\mathrm{NO}_{3}{ }^{-}$which act differently on the chemical composition of plants (Nurzyński and Michałojć, 1998).

Therefore, the objectives of this study were to determine the effects of urea and urea-formaldehyde as $\mathrm{N}$ sources applied alone at different rates or combined with potassium sulphate, on nutrient contents, yield quantity and quality of lettuce plant, and some soil chemical properties.

\section{Material and Methods}

A field experiment was conducted on a sandy soil in the private farm of Ahmed Orabi organization, Cairo Governorate, Egypt, between 15th November 2009 and 15 January 2010. Some physical and chemical properties of the top layer of soil (up to $30 \mathrm{~cm}$ ) were determined and given in Table 1.

Table 1. Physical and chemical properties of the studied soil

\begin{tabular}{|c|c|}
\hline Soil properties & Value \\
\hline \multicolumn{2}{|l|}{ Particle size distribution } \\
\hline Coarse sand (\%) & 75.00 \\
\hline Fine sand (\%) & 20.00 \\
\hline Silt (\%) & 3.00 \\
\hline Clay (\%) & 2.00 \\
\hline Soil Texture & Sand \\
\hline pH (saturated soil paste) & 8.10 \\
\hline Ec $\left(\mathrm{dSm}^{-1}\right)$ in soil paste extract & 1.80 \\
\hline \multicolumn{2}{|c|}{ Soluble ions $\left(\mathrm{mmol}_{\mathrm{c}} \mathrm{L}^{-1}\right)$ in soil paste extract: } \\
\hline $\mathrm{CO}_{3}^{2-}$ & 0.00 \\
\hline $\mathrm{HCO}_{3}^{-}$ & 1.35 \\
\hline $\mathrm{Cl}-$ & 7.84 \\
\hline $\mathrm{SO}_{4}{ }^{2-}$ & 9.28 \\
\hline $\mathrm{Ca}^{2+}$ & 2.67 \\
\hline $\mathrm{Mg}^{2+}$ & 1.45 \\
\hline $\mathrm{Na}^{+}$ & 14.16 \\
\hline $\mathrm{K}^{+}$ & 0.19 \\
\hline Available N (mg kg-1) & 24.85 \\
\hline Available $\mathrm{P} \quad\left(\mathrm{mg} \mathrm{kg}^{-1}\right)$ & 4.4 \\
\hline Available $\mathrm{K}\left(\mathrm{mg} \mathrm{kg}^{-1}\right)$ & 171.6 \\
\hline Available Fe $\left(\mathrm{mg} \mathrm{kg}^{-1}\right)$ & 2.00 \\
\hline Available $\mathrm{Zn}\left(\mathrm{mg} \mathrm{kg}^{-1}\right)$ & 2.30 \\
\hline Available $\mathrm{Mn} \quad\left(\mathrm{mg} \mathrm{kg}^{-1}\right)$ & 1.20 \\
\hline
\end{tabular}

Seeds of lettuce, Dark green cultivar, were planted in a Try, and kept at greenhouse state place and environmental conditions. The seedlings of lettuce were then transplanted in plots $(3.5 \times 3 \mathrm{~m})$ at the field, spacing $25 \mathrm{~cm}$ within row and $50 \mathrm{~cm}$ between rows. Plants were irrigated by drip irrigation systems and received all agricultural practices needed such as weed control and pest management. Two sources of $\mathrm{N}$ were used, urea $(46.5 \% \mathrm{~N})$ and urea-formaldehyde $(38 \% \mathrm{~N})$ at the rates of $0,60,90$ and $120 \mathrm{~kg} \mathrm{~N} \mathrm{ha}^{-1}$. Potassium in form of $\mathrm{K}_{2} \mathrm{SO}_{4}$ was applied at a rate of $75 \mathrm{~kg} \mathrm{~K}_{2} \mathrm{O}$ ha-1 equivalent to $62.25 \mathrm{~kg} \mathrm{~K} \mathrm{ha}^{-1}$. Phosphorus was applied uniformly as calcium superphosphate at a rate of $30 \mathrm{~kg} \mathrm{P}_{2} \mathrm{O}_{5} \mathrm{ha}^{-1}$ equivalent to $12.5 \mathrm{~kg} \mathrm{P} \mathrm{ha}^{-1}$. Cattle manure was added to the soil at a rate of $40 \mathrm{~m}^{3} \mathrm{ha}^{-1}$ before land preparation. Urea-formaldehyde as a slow $\mathrm{N}$ release form was applied during the land preparation. During the growing season urea as a fast $\mathrm{N}$ release form and $\mathrm{K}\left(\mathrm{K}_{2} \mathrm{SO}_{4}\right)$ were added to the soil at one week intervals at the rates of $20 \mathrm{~kg} \mathrm{~N} \mathrm{ha}^{-1}$ and $15 \mathrm{~kg}$ 
$\mathrm{K} \mathrm{ha}^{-1}$ with irrigation water, respectively. Treatments were arranged in a randomized complete block design with three replicates.

At the harvesting date five plants were sampled from each plot. The fresh weight of each plant was determined using electronic balance. Then plant samples were dried in an oven at $70{ }^{\circ} \mathrm{C}$ for $72 \mathrm{~h}$ and milled.

Dry matter was used for plant nutrient content analysis in tissue. Total $\mathrm{N}$ content was determined by the Kjeldahl method (Nelson and Sommers, 1980). Potassium was determined by emission flame photometer, while iron ( $\mathrm{Fe})$, manganese $(\mathrm{Mn})$ and zinc $(\mathrm{Zn})$ were determined by the atomic absorption spectro photometer (Perkin Elmer Analyst 100). To obtain plant sap, complete plants were smashed until a homogenous paste was obtained. Then $\mathrm{NO}_{3}{ }^{-}$was determined based on the procedures compiled by Chapman and Pratt (1978). Protein was determined multiplying total N percentage by 6.25 .

After harvesting, soil samples from each treatment were collected, mixed, air-dried, sieved by a 2-mm wire mesh sieve and used to determine soil pH and electrical conductivity (EC) (Smith and Doran, 1996). Phosphorous was determined colorimetrically using the molybdephosphoric blue colour method in sulphuric acid system as described by Jackson (1958). Potassium was extracted with neutral $1 \mathrm{~N}$ ammonium acetate and its amount was estimated by emission flame photometer (Jackson, 1958).

\section{Statistical analysis}

All data were subjected to statistical analysis of variance and treatment means were compared according to the Least Significant Differences (LSD) test method as described by Snedecor and Cochran (1980).

\section{Results and Discussion}

\section{Fresh and dry weights of lettuce plants}

The fresh and dry weights of lettuce increased when they were fertilized with different sources of $\mathrm{N}$ alone or combination with $\mathrm{K}_{2} \mathrm{SO}_{4}$ over the control (Table 2).

Table 2. Effects of different $\mathrm{N}$ sources and $\mathrm{K}$ fertilization on fresh, dry and total fresh weights of lettuce plant.

\begin{tabular}{|c|c|c|c|c|c|}
\hline $\begin{array}{l}\text { Sources } \\
\text { of } \mathrm{N}\end{array}$ & $\begin{array}{c}\text { Rates of } \\
\mathrm{N} \text { applied } \\
\left(\mathrm{kg} \mathrm{ha}^{-1}\right)\end{array}$ & $\begin{array}{c}\text { Rates of } \\
\mathrm{K}_{2} \mathrm{O} \text { applied } \\
\left(\mathrm{kg} \mathrm{ha}^{-1}\right)\end{array}$ & $\begin{array}{c}\text { Fresh } \\
\text { weight } \\
\text { (g plant }^{-1} \text { ) }\end{array}$ & $\begin{array}{l}\text { Dry weight } \\
\text { (g plant }^{-1} \text { ) }\end{array}$ & $\begin{array}{c}\text { Total fresh } \\
\text { weight } \\
\text { (tonnes ha-1) }\end{array}$ \\
\hline \multirow[t]{2}{*}{ Control } & 0 & 0 & 245.00 & 28.00 & 7.84 \\
\hline & 60 & & 294.32 & 45.10 & 9.41 \\
\hline \multirow[t]{2}{*}{ Urea } & 90 & 0 & 362.12 & 67.34 & 11.58 \\
\hline & 120 & & 328.11 & 68.32 & 12.73 \\
\hline \multirow[t]{2}{*}{ Mean } & & & 328.18 & 60.25 & 11.24 \\
\hline & 60 & & 343.07 & 44.21 & 10.97 \\
\hline \multirow[t]{2}{*}{ Urea-form. } & 90 & 0 & 426.23 & 78.25 & 13.63 \\
\hline & 120 & & 490.51 & 81.44 & 15.69 \\
\hline \multirow[t]{2}{*}{ Mean } & & & 419.96 & 67.96 & 13.43 \\
\hline & 60 & & 407.24 & 58.20 & 13.03 \\
\hline \multirow[t]{2}{*}{ Urea } & 90 & 75 & 520.03 & 81.23 & 13.44 \\
\hline & 120 & & 561.56 & 87.84 & 17.96 \\
\hline \multirow[t]{2}{*}{ Mean } & & & 496.27 & 75.75 & 14.81 \\
\hline & 60 & & 483.96 & 99.33 & 15.48 \\
\hline \multirow[t]{2}{*}{ Urea-form. } & 90 & 75 & 553.31 & 102.12 & 17.70 \\
\hline & 120 & & 627.09 & 123.14 & 20.06 \\
\hline Mean & & & 554.78 & 108.19 & 17.74 \\
\hline \multicolumn{2}{|c|}{ LSD at 0.05 level } & & 21.65 & 2.01 & 0.92 \\
\hline
\end{tabular}

It is evidence that increasing level of $\mathrm{N}$ fertilizer was associated with an increase in both fresh and dry weights of lettuce plants where the highest increase was observed at $120 \mathrm{~kg} \mathrm{~N} \mathrm{ha}^{-1}$. However, the highest level of urea-formaldehyde induced significantly higher fresh and dry weights when compared with the plants fertilized with the highest rate of urea. These findings concur with the results obtained by Guertal (2009) who found that the use of slow release $\mathrm{N}$ fertilizers such as urea-formaldehyde or sulphur coated 
urea increased crop yield when compared with the standard split application of soluble N. Using slow release $\mathrm{N}$ fertilizers in vegetables reduces the environmental risk and production costs.

Applications of $\mathrm{N}$ and $\mathrm{K}$ at higher levels significantly increased the fresh and dry weights of the lettuce plants. When urea was combined with $\mathrm{K}$, higher fresh and dry weights were achieved than that of plants fertilized with urea alone. These results are in agreement with the findings of Gülser (2005) and Stagnari et al. (2007) who indicate that the yield of spinach was increased by increasing the rates of $\mathrm{N}$ fertilizer. Nurzyńska-Wierdak (2009) indicated that the increase in the amounts of $\mathrm{N}$ and $\mathrm{K}$ application generally contributed to an increase in fresh leaf weight and yield. Abdel-Motagally and Osman (2010) found that increasing $\mathrm{N}$ and $\mathrm{K}$ fertilizer rates resulted to a significant increase in yield compared to the other treatments. Volterrani et al. (1999) indicated that the use of slow release $\mathrm{N}$ fertilizers made it possible to reduce $\mathrm{N}$ loss by leaching. Also, Hegde (1997) used slow release $\mathrm{N}$ fertilizers for some Solanaceous vegetable crops and found that these fertilizers were very effective in increasing nutrient use efficiency, crop production and reducing nutrient losses

\section{Nutrient contents in lettuce plants}

The application of different levels of $\mathrm{N}$ from different sources alone or combined with potassium sulphate increased the concentrations of N, P, K and Ca in the lettuce plants compared with control plants (Table 3). In general, the highest values of $\mathrm{N}$ concentration in lettuce plants were recorded in plants fertilized with 120 $\mathrm{kg} \mathrm{N} \mathrm{ha}^{-1}$ regardless of the sources of $\mathrm{N}$, whereas, the highest values of $\mathrm{P}, \mathrm{K}$ and $\mathrm{Ca}$ amounts in the lettuce plant were achieved in the plants received $90 \mathrm{~kg} \mathrm{~N}^{-1}$ irrespective to the form of $\mathrm{N}$ fertilize.

Table 3. Nutrient contents in the lettuce plants as affected by the use of different sources of nitrogen and potassium fertilizer.

\begin{tabular}{|c|c|c|c|c|c|c|c|c|c|}
\hline \multirow{3}{*}{$\begin{array}{l}\text { Sources } \\
\text { of N }\end{array}$} & \multirow{3}{*}{$\begin{array}{l}\mathrm{N} \text { doses } \\
\left(\mathrm{kg} \mathrm{ha}^{-1}\right)\end{array}$} & \multirow{3}{*}{$\begin{array}{l}\mathrm{K}_{2} \mathrm{O} \text { doses } \\
\left(\mathrm{kg} \mathrm{ha}^{-1}\right)\end{array}$} & \multicolumn{7}{|c|}{ Nutrient concentration } \\
\hline & & & $\mathrm{N}$ & $\mathrm{P}$ & $\mathrm{K}$ & $\mathrm{Ca}$ & $\mathrm{Fe}$ & $\mathrm{Zn}$ & $\mathrm{Mn}$ \\
\hline & & & \multicolumn{3}{|c|}{$(\%)$} & \multicolumn{4}{|c|}{$\left(\mathrm{mg} \mathrm{kg}^{-1}\right)$} \\
\hline Control & 0 & 0 & 1.11 & 0.21 & 2.88 & 1.14 & 167.23 & 15.92 & 102.00 \\
\hline \multirow{3}{*}{ Urea } & 60 & & 2.57 & 0.25 & 4.02 & 1.68 & 347.21 & 22.98 & 123.00 \\
\hline & 90 & 0 & 3.28 & 0.29 & 3.16 & 2.14 & 478.09 & 25.63 & 130.78 \\
\hline & 120 & & 3.61 & 0.27 & 3.57 & 1.99 & 578.98 & 28.27 & 145.04 \\
\hline Mean & & & 3.15 & 0.27 & 3.58 & 1.93 & 468.09 & 25.62 & 132.94 \\
\hline \multirow{3}{*}{$\begin{array}{l}\text { Urea- } \\
\text { formaldehyde }\end{array}$} & 60 & & 3.14 & 0.35 & 4.44 & 2.34 & 486.23 & 26.90 & 114.40 \\
\hline & 90 & 0 & 3.92 & 0.31 & 4.76 & 2.91 & 573.98 & 31.67 & 130.40 \\
\hline & 120 & & 4.22 & 0.30 & 3.91 & 2.55 & 689.02 & 39.53 & 167.11 \\
\hline Mean & & & 3.76 & 0.32 & 4.37 & 2.60 & 583.07 & 32.70 & 137.70 \\
\hline \multirow{3}{*}{ Urea } & 60 & & 2.14 & 0.37 & 4.26 & 1.56 & 465.21 & 26.09 & 144.76 \\
\hline & 90 & 75 & 3.12 & 0.41 & 4.98 & 2.02 & 564.46 & 28.00 & 152.89 \\
\hline & 120 & & 3.31 & 0.36 & 4.99 & 1.62 & 654.66 & 33.64 & 155.25 \\
\hline Mean & & & 2.85 & 0.38 & 4.74 & 1.73 & 561.44 & 29.24 & 150.96 \\
\hline \multirow{3}{*}{$\begin{array}{l}\text { Urea- } \\
\text { formaldehyde }\end{array}$} & 60 & & 3.00 & 0.44 & 4.75 & 1.88 & 687.93 & 31.17 & 148.38 \\
\hline & 90 & 75 & 3.58 & 0.55 & 5.76 & 2.15 & 756.23 & 38.88 & 168.98 \\
\hline & 120 & & 4.11 & 0.51 & 5.43 & 2.34 & 869.76 & 43.64 & 189.36 \\
\hline Mean & & & 3.56 & 0.51 & 5.31 & 2.12 & 771.30 & 37.89 & 168.90 \\
\hline LSD at 0.05 & & & 0.04 & 0.01 & 0.10 & 0.08 & 4.51 & 1.78 & 2.56 \\
\hline
\end{tabular}

Increasing the rates of $\mathrm{N}$ up to $90 \mathrm{~kg} \mathrm{~N}^{-1}$ was associated with an increase in $\mathrm{P}, \mathrm{K}$ and Ca concentrations in the lettuce plants. However, increasing the rates of $\mathrm{N}$ beyond this level was accompanied by a decrease in the contents of $\mathrm{P}, \mathrm{K}$ and $\mathrm{Ca}$, but this decrease was still higher than that of control, presumably due to the dilution on these nutrients in plant tissues. Similar results were obtained by Stagnari et al. (2007) who found that K content in spinach plants was decreased by increasing rates of $\mathrm{N}$ up to $200 \mathrm{~kg} \mathrm{ha}^{-1}$. Zarei (1995) reported that application of high rates of $\mathrm{N}$ decreased the absorption of $\mathrm{P}$ in spinach plants. Likewise, the mean values of N, P, K and Ca in N applied as urea-formaldehyde form were higher than that in $\mathrm{N}$ applied as urea form.

When $\mathrm{N}$ fertilizer was applied with potassium sulphate, the amounts of $\mathrm{N}$ and $\mathrm{Ca}$ in plants were lower than that in plants fertilized with higher rates of $\mathrm{N}$ alone. In contrast, higher values of $\mathrm{P}$ and $\mathrm{K}$ contents were registered in the plants received a combination of $\mathrm{N}$ and potassium sulphate. Results also indicated that an 
application of potassium sulphate + urea-formaldehyde increased the values of $\mathrm{N}, \mathrm{P}, \mathrm{K}$ and Ca contents and the mean values were $3.56 \%, 0.51 \%, 5.31 \%$ and $2.12 \%$, respectively.

Although, the amount of $\mathrm{Fe}, \mathrm{Zn}$ and $\mathrm{Mn}$ increased considerably in the plant tissues, when $\mathrm{N}$ was applied alone or combination with potassium sulphate compared with the control (Table 3). Urea-formaldehyde combined with potassium sulphate escalated the values of $\mathrm{Fe}, \mathrm{Zn}$ and $\mathrm{Mn}$ by 771.30, 37.89 and 168.90 $\mathrm{mg} / \mathrm{kg}$, respectively. These results could be attributed to the soluble ions associated with the applied potassium which significantly increased the availability of micronutrients in sandy soil, probably due to physiological acidification of the rhizosphere. In addition, probably the apparent losses of applied $\mathrm{N}$ in ureaform treatment were low and the high uptakes of $\mathrm{N}$ promoted growth in lettuce plants, and thus stimulated more uptakes of the micronutrients. Hegde (1997) reported similar findings that the additional supply of sulphur from potassium sulphate contributed to the increase in S content in the lettuce plants. Böhme and Lua (1997) showed that $\mathrm{K}$ had beneficial effects on micronutrients uptake, transport and its availability in plants. Jurkowska and Rogoz (1981) reported that soil fertilization with nitrogen in the form of ammonium nitrate, calcium nitrate, urea and ammonium sulphate contributed to increased uptakes of $\mathrm{Fe}, \mathrm{Mn}, \mathrm{Zn}, \mathrm{Cu}$, Mo and B by barley plants. Hao et al. (2007) indicated that the transportation ability of micronutrients from root to shoot was improved with $\mathrm{N}$ fertilizer application.

\section{Nitrate accumulation in lettuce}

Effects of different sources and rates of $\mathrm{N}$ when applied alone or combined with potassium sulphate on nitrate concentration in plant tissues are given in Table 4. The application of $\mathrm{N}$ fertilizer increased the nitrate contents of lettuce plants compared with the control. These findings are in consistent with those of Ahmadi et al. (2010) who found that the highest nitrate content was observed at the highest fertilizer level (200 kg N $\mathrm{ha}^{-1}$ ) compared with the control. Urea application caused greater nitrate content in lettuce plant than the urea-formaldehyde that prevented excessive accumulation of $\mathrm{NO}_{3}$ - in the vegetables, including lettuce plants and leaching of $\mathrm{N}$ from the soil (Hartrath, 1986; Guertal, 2009). Lorenz (1978) suggested some methods for reducing $\mathrm{NO}_{3}{ }^{-}$content in spinach which include use of low nitrate content cultivar, appropriate $\mathrm{N}$ fertilizer, application of ammoniac fertilizer associated with application of nitrification inhibitor, split $\mathrm{N}$ application rather than basal application and utilization of slow-release fertilizer.

Table 4. The effect of different sources of $\mathrm{N}$ and potassium sulphate on the content of nitrate and total protein of lettuce plant.

\begin{tabular}{llccc}
\hline $\begin{array}{l}\text { Sources } \\
\text { of } \mathrm{N}\end{array}$ & $\begin{array}{l}\text { Rates of } \\
\mathrm{N} \text { applied } \\
\left(\mathrm{kg} \mathrm{ha}^{-1}\right)\end{array}$ & $\begin{array}{c}\text { Rates of } \\
\mathrm{K}_{2} \mathrm{O} \text { applied } \\
\left(\mathrm{kg} \mathrm{ha}^{-1}\right)\end{array}$ & $\begin{array}{c}\text { Nitrate content } \\
\left(\mathrm{mg} \mathrm{kg}^{-1}\right)\end{array}$ & $\begin{array}{c}\text { Total protein } \\
(\%)\end{array}$ \\
\hline Control & 0 & 0 & 372.00 & 13.18 \\
& 60 & & 1420.46 & 16.06 \\
Urea & 90 & 0 & 2729.23 & 20.50 \\
& 120 & & 2987.36 & 22.56 \\
Mean & & & 2379.01 & 19.70 \\
& 60 & 0 & 930.73 & 19.62 \\
Urea- & 90 & & 1080.62 & 24.50 \\
formaldehyde & 120 & & 1730.65 & 26.38 \\
Mean & & & 1247.11 & 23.50 \\
& 60 & 75 & 1283.00 & 16.50 \\
Urea & 90 & & 1893.75 & 22.00 \\
& 120 & & 2001.78 & 24.44 \\
Mean & & & 1726.17 & 20.98 \\
& 60 & 75 & 830.91 & 20.25 \\
Urea- & 90 & & 909.81 & 25.75 \\
formaldehyde & 120 & & 1207.87 & 27.25 \\
Mean & & & 982.86 & 24.16 \\
LSD at 0.05 & & & 4.88 & 0.14 \\
\hline
\end{tabular}

A higher decrease in nitrate content was recorded in plants fertilized with a combination of $\mathrm{N}$ and potassium sulphate than plants without K (Table 4). Ahmed et al. (2000) demonstrated that application of P and K 
contributed to a decrease in nitrate concentration even when $\mathrm{N}$ was applied at a high rate. Similarly, Zong et al. (1997) proved that the increase in the rates of $\mathrm{K}$ fertilizer decreased nitrate accumulation in certain vegetables. Wang and Ito (1998) reported that increasing application rates of $\mathrm{K}$ fertilizers reduced nitrate accumulation in some vegetable crops. Moreover, Ali et al. (1985) reported that the enzyme nitrate reductase activity in the leaves and stems of rice plants supplied with $\mathrm{K}$ was higher than in those plants that are deficient in K. Sulphur deficiency therefore might lead to an increase in nitrate contents (Maynard et al., 1976).

\section{Protein content in lettuce plants}

The results showed that total protein contents in the lettuce plants increased as a result of application of different $\mathrm{N}$ forms used alone or combined with potassium sulphate compared with the control (Table 4). These findings showed that $\mathrm{N}$ fertilization increased absorption of $\mathrm{N}$ from soil and consequently increased the protein content of plant tissues. Investigation conducted by Mo et al. (1991) revealed that an application of slow release $\mathrm{N}$ fertilizer increased yield, amino acid and chlorophyll contents of soybean when compared with the ordinary urea.

\section{Soil properties after crop harvesting}

$\mathrm{N}$ fertilizer caused a reduction in the values of EC and $\mathrm{pH}$ of the soil compared with unfertilized soil (Table 5). When $\mathrm{N}$ was applied as urea-formaldehyde, EC and $\mathrm{pH}$ reduced slightly compared to application of urea. Utilizing $\mathrm{N}$ fertilizers either as urea or urea-formaldehyde elevated the amount of $\mathrm{N}, \mathrm{P}$ and $\mathrm{K}$ in the soil when compared with control. Application of different sources of $\mathrm{N}$ with combination of potassium sulphate increased the EC of the soil above that of soil fertilized with slow release $\mathrm{N}$ fertilizer alone, application $\mathrm{N}$ and potassium sulphate together decreased the $\mathrm{pH}$ and the amounts of $\mathrm{N}$ and $\mathrm{P}$ in the soil, but increased the quantity of $\mathrm{K}$.

Table 5. Some properties of the soil after harvesting the lettuce plants

\begin{tabular}{|c|c|c|c|c|c|c|c|}
\hline \multirow{2}{*}{$\begin{array}{l}\text { Sources } \\
\text { of } \mathrm{N}\end{array}$} & \multirow{2}{*}{$\begin{array}{l}\text { Rates of } \\
\mathrm{N} \text { applied } \\
\left(\mathrm{kg} \mathrm{ha}^{-1}\right)\end{array}$} & \multirow{2}{*}{$\begin{array}{l}\text { Rates of } \\
\mathrm{K}_{2} \mathrm{O} \text { applied } \\
\left(\mathrm{kg} \mathrm{ha}^{-1}\right)\end{array}$} & \multirow{2}{*}{$\begin{array}{c}\mathrm{EC} \\
\left(\mathrm{dSm}^{-1}\right)\end{array}$} & \multirow{2}{*}{$\begin{array}{c}\mathrm{pH} \\
(1: 2.5)\end{array}$} & \multicolumn{3}{|c|}{$\begin{array}{l}\text { Available nutrients } \\
\left(\mathrm{mg} \mathrm{kg}^{-1}\right)\end{array}$} \\
\hline & & & & & $\mathrm{N}\left(\mathrm{NH}_{4}+\mathrm{NO}_{3}\right)$ & $\mathrm{P}$ & $\mathrm{K}$ \\
\hline \multirow[t]{2}{*}{ Control } & 0 & 0 & 1.22 & 7.88 & 8.34 & 3.20 & 134.21 \\
\hline & 60 & & 1.00 & 7.58 & 12.89 & 5.21 & 145.90 \\
\hline \multirow[t]{2}{*}{ Urea } & 90 & 0 & 1.02 & 7.36 & 16.11 & 5.90 & 159.56 \\
\hline & 120 & & 1.11 & 7.45 & 18.92 & 6.30 & 160.33 \\
\hline \multirow[t]{2}{*}{ Mean } & & & 1.04 & 7.46 & 15.97 & 5.80 & 155.26 \\
\hline & 60 & & 0.98 & 7.59 & 12.24 & 5.42 & 155.89 \\
\hline \multirow[t]{2}{*}{ Urea-formaldehyde } & 90 & 0 & 0.85 & 7.37 & 18.90 & 5.90 & 176.90 \\
\hline & 120 & & 0.81 & 7.23 & 22.56 & 7.79 & 180.23 \\
\hline Mean & & & 0.88 & 7.39 & 17.90 & 6.37 & 171.00 \\
\hline \multirow[t]{3}{*}{ Urea } & 60 & 75 & 1.32 & 7.12 & 10.21 & 4.25 & 201.75 \\
\hline & 90 & & 1.33 & 7.11 & 13.78 & 4.89 & 223.90 \\
\hline & 120 & & 1.35 & 7.03 & 15.42 & 4.90 & 267.35 \\
\hline \multirow[t]{2}{*}{ Mean } & & & 1.33 & 7.06 & 13.13 & 4.68 & 231.00 \\
\hline & 60 & & 1.01 & 7.10 & 10.34 & 4.90 & 247.94 \\
\hline \multirow[t]{2}{*}{ Urea- formaldehyde } & 90 & 75 & 1.11 & 7.06 & 14.45 & 5.11 & 288.43 \\
\hline & 120 & & 1.12 & 7.01 & 16.90 & 5.42 & 297.41 \\
\hline Mean & & & 1.08 & 7.05 & 13.89 & 5.14 & 277.92 \\
\hline LSD at 0.05 & & & 0.011 & 0.01 & 0.11 & 0.02 & 0.61 \\
\hline
\end{tabular}

\section{Conclusion}

Slow-release nitrogen fertilizers such as urea formaldehyde can be used as a pre-plant $\mathrm{N}$ nutrient source. It reduces production costs and eliminates the need for multiple applications of soluble $\mathrm{N}$ fertilizers. Furthermore, slow-release nitrogen fertilizers were able to decrease nitrate content of plants compared with urea application.

\section{References}


Abdel-Motagally, F.M.F., Osman E. A., 2010. Effect of nitrogen and potassium fertilization combinations on productivity of two sunflower cultivars under East-of El-ewinate conditions. American-Eurasian Journal of Agricultural \& Environmental Sciences 8(4): 397-401.

Ahmed, A.H.H., Khalil, M.K., Farrag, A.M., 2000. Nitrate accumulation, growth, yield and chemical composition of Rocket (Eruca vesicaria subsp. sativa) plant as affected by NPK fertilization, kinetin and salicylic acid. Proceedings of ICEHM 2000, Cairo University, Egypt, pp. 495-508.

Ahmadi, H., Akbarpour, V., Dashti F, Shojajaeian, A., 2010. Effect of different levels of nitrogen fertilizer on yield, nitrate accumulation and several quantitative attributes of fove Iranian spinach accessions. American-Eurasian Journal of Agricultural \& Environmental Sciences 8(4): 468-473.

Ali, A.A., Ikeda, M., Yamada, Y., 1985. Absorption, translocation and assimilation of ammonium-and nitrate -nitrogen in rice plants as affected by the supply of potassium, calcium and magnesium. Journal of the Faculty of Agriculture, Kyushu University 30(2-3): 113-124.

Böhme, M., Lua, H., 1997. Influence of mineral and organic treatments in the rizosphere on the growth of tomato plants. Acta Horticulturae 450: 161-168.

Bozkurt, S.M., Mansuroğlu, G.S., Kara, M., Önder, S., 2009. Responses of lettuce to irrigation levels and nitrogen forms. African Journal of Agricultural Research 4(11): 1171-1178.

Breimer, T., 1982. Environmental factors and cultural measures affecting the nitrate content in spinach. Fertilizer Research 3 (3):191-292.

Byrne, C., Maher, M.J., Hennerty, M.J., 2001. Reducing the nitrogen content of protected lettuce crops. Irish Agriculture and Food Development Authority. Dublin: University College, $19 \mathrm{p}$.

Cash, D., Funston, R., King, M., Wichman, D., 2002. Nitrate toxicity of Montana forages. Montana State University, Extension MontGuide. MT 200205 AG reviewed 5/06. Available at [access date: 05.12.2015]: http://www.msuextension.org/carbon/Documents/ag\%20nit\%20tox\%20mt.pdf

Chapman, H.D., Pratt, P.F., 1978. Methods of analysis for soils, plants and waters. Division of Agricultural Sciences, University of California, Berkeley, USA. 3043 pp.

Gulser, F., 2005. Effects of ammonium sulphate and urea on $\mathrm{NO}_{3}{ }^{-}$and $\mathrm{NO}_{2}{ }^{-}$accumulation, nutrient contents and yield criteria in spinach. Scientia Horticulturae 106 (3): 330-340.

Gülser, F., Sönmez, F., Boysan, S., 2010. Effect of calcium nitrate and humic acid applications on growth and yield criteria of pepper seedling under salt stress. Journal of Environmental Biology 31(5) : 873-876.

Guertal, E.A., 2009. Slow release nitrogen fertilizers in vegetable production: A Review. HortTechnology 19(1): 16-19.

Hao, H.L., Wei, Y.Z., Xiao, X.E., Ying, F., Wu, C.Y., 2007. Effects of different nitrogen fertilizer levels on Fe, Mn, Cu and Zn concentrations in shoot and grain quality in rice (Oryza sativa). Rice Science 14(4): 289-294.

Hartrath, H., 1986. Nitrogen should be released slowly. Gemuse 22(8): 332-334.

Hegde, D.M., 1997. Nutrient requirements of solanaceous vegetable crops. Food and Fertilizer Technology Centre for the Asian and Pasific Region. Extension Bulletins. Available at [access date: 05.12.2015]: http://www.agnet.org/file_view.php?file_url=/htmlarea_file/library/20110801133428/eb441.pdf

Jackson, M.L., 1958. Soil Chemical Analysis, Prentice Hall Inc. Englewood Cliffs, New Jersey, USA. 498p.

Jurkowska, H., Rogoz, A., 1981. The effect of the form of nitrogen and its dose on the content of macro- and microelements of plants Part II: Microelements. Acta Agraria et Silvestria Series Agraria 20: 121-131.

Lorenz, O.A., 1978. Potential nitrate levels in edible plant parts. In: Nitrogen in the environment. Vol.2, Soil-PlantNitrogen relationship. Nielsen, D.R., MacDonald, J.G., (Eds.). Academic Press, New York, USA. pp.201-219.

Maynard, D.N., Barker, A.V., Minotti, P.L., Peck, N.H., 1976. Nitrate accumulation in vegetables. Advances in Agronomy 28: 71-118.

Mo, H., Zhao, X.C., Wang, F.S., 1995. Effect of slow-release urea on increasing soybean yield. Soybean Science 10(4): 335338.

McCarty, L.B., 2005. Best golf course management practices. $2^{\text {nd }}$ Edition, Prentice Hall Inc. Upper Saddle River, New Jersey, USA. 896 p.

Nelson, D.W., Sommers, L.E., 1982. Total carbon, organic carbon, and organic matter. In: Methods of Soil Analysis, Part 2, Chemical and Microbiological Properties, Second Edition. Number 9, Page, A.L., Keeney, D. R., Baker, D.E., Miller, R.H., Ellis, R. Jr., Rhoades, J.D. (Eds.). ASA-SSSA, Madison, Wisconsin, USA. pp.539-580.

Nurzyński, J., Michałojc, Z., 1998. Plonowanie pomidora uprawianego w wełnie mineralnej w zależności od nawożenia potasowego. Zesz. Nauk AR Kraków 333(57): 235-239. [in Polish]

Nurzyńska-Wierdak, R., 2009. Growth and yield of garden rocket (Eruca sativa Mill) affected by nitrogen and potassium fertilization. Acta Scientiarum Polonorum - Hortorum Cultus 8(4): 23-33.

Snedecor, G.W., Cochran, W.G., 1980. Statistical methods. $7^{\text {th }}$ Edition, Ames: Iowa State University Press. USA. 480p.

Stagnari, F., Di Bitetto, V., Pisante, M., 2007. Effect of N fertilization and rates on yield, safety and nutrients in processing spinach genotypes. Scientia Horticulturae 111(4): 225-233.

Smith, J.L., Doran, J.W., 1996. Measurement and use of $\mathrm{pH}$ and electrical conductivity for soil quality analysis. In: Methods for assessing soil quality. Doran, J.W., Jones, A.J. (Eds.). Soil Science Society of America Special Publication No. 49, pp. 169-185. 
Tisdale, S.L., Nelson, W.L., Beaton, J.D., Havlin, J.L., 1991. Soil fertility and fertilizers. $5^{\text {th }}$ Edition, Macmillan Publishing Company, New York, USA. 634 p.

Volterrani, M., Gaetani, M., Grossi, N., Pardini, G., Miele, S., Magni, S., 1999. The use of organic fertilizers on turf (Lolium perenne L.). Nitrogen uptake and loss dynamic. Rivista di Agronomia 33(1): 34-39.

Wang, X.F., Ito, T., 1998. Effect of lowering nitrate nitrogen and elevating potassium concentrations in the nutrient solution on the growth, yield and $\mathrm{NO}_{3}$ content in spinach grown in hydroponics. Journal of the Japanese Society for Horticultural Science 67(1): 74-80.

WHO, 1995. World Health Organization. The world health report 1995. Bridging the gaps. Geneva, Switzerland. Available at [access date: 05.12.2015]: http://www.who.int/whr/1995/en/whr95_en.pdf?ua=1

Zarei, H., 1995. Investigation of nitrate accumulation in vegetables lettuce and spinach in relation to nitrogen fertilizers. MSc. Thesis, Tarbiat Modarres University. Tehran, Iran

Zong, N.W., Song, Z.Y., Yong, L.X., 1997. The effect of different K sources on yield and quality of some vegetable crops. Acta Agriculturae Zhejiangensis (China) 9 (3): 143-148. [in Chinese] 